\title{
Increasing use of exotic forestry tree species as refuges from nest predation by the Critically Endangered Mauritius fody Foudia rubra
}

\author{
Andrew Cristinacce, Richard A. Switzer, Ruth E. Cole, Carl G. Jones and
}

DIANA J. BELL

\begin{abstract}
The population of the Critically Endangered Mauritius fody Foudia rubra fell by 55\% over 1975-1993 because of habitat destruction and predation. The species was believed to be dependent on a small grove of introduced, non-invasive Cryptomeria japonica trees that offered protection from nest predation. We investigated the current population size and distribution of the fody and compared nesting success in forestry plantations to that of a released population on an offshore island. The population size on the mainland has remained stable over the past 10 years, with increases in pine Pinus spp. plantations, but continues to decline in areas of predominantly native vegetation. Only $16 \%$ of pairs found were estimated to nest in native tree species. Up to $81 \%$ of nest failures on the mainland were attributed to predation but nesting success in C. japonica and pine trees was similar to that of a released population on a predator-free offshore island. The mainland population is increasingly dependent on plantations for survival and we predict this will continue. Management and protection of non-invasive exotic species, together with creation of native habitat refuges on the mainland and offshore islands can be used to increase numbers of threatened birds in areas where predator control is not feasible.
\end{abstract}

Keywords Foudia rubra, introduced predators, island endemics, Mauritius fody, nesting success.

\section{Introduction}

T sland species have accounted for $>90 \%$ of bird extinc1 tions in the last 400 years, with introduced exotic species being the most common cause (Johnson \& Stattersfield, 1990; Duncan \& Blackburn, 2007). Invasive species have been identified as one of the principal threats to $50 \%$ of the most

Andrew Cristinacce* (Corresponding author), Richard A. Switzer, Ruth E. Cole and Carl G. Jones ${ }^{\dagger}$ Mauritius Wildlife Foundation, Grannum Road, Vacoas, Mauritius. E-mail a_cristinacce@hotmail.com

Diana J. Bell School of Biological Sciences, University of East Anglia, Norwich, UK

${ }^{*}$ Also at: School of Biological Sciences, University of East Anglia, Norwich, UK

${ }^{\dagger}$ Also at: Durrell Wildlife Conservation Trust, Trinity, Jersey, UK Channel Islands.

Received 12 September 2007. Revision requested 5 November 2007. Accepted 7 January 2008 threatened bird species (Butchart et al., 2006). Rats are the most widespread and successful invaders on islands, capable of causing dramatic declines in local bird populations (Penloup et al., 1997; Towns et al., 2006). The Mauritian avifauna has also been adversely affected by introduced crab-eating macaques Macaca fascicularis, a predator rarely found as an exotic pest species on oceanic islands (Johnson \& Stattersfield, 1990).

The population size of the Mauritius fody Foudia rubra, categorized as Critically Endangered on the IUCN Red List (IUCN, 2007), decreased by $55 \%$ over 1975-1993 from an estimated $247-260$ to $104-120$ pairs, with a parallel contraction in extent of occurrence from c. $34 \mathrm{~km}^{2}$ to $14.7 \mathrm{~km}^{2}$ (Safford, 1997a). A more recent survey suggests that population size has remained fairly stable since 1993 but that fodies have expanded into areas of exotic forest habitat (Nichols et al., 2002). Safford (1997b) suggested the primary threat to the Mauritius fody lay with nest predation by introduced mammals, namely black rats Rattus rattus and crab-eating macaques. Rats are believed to have been introduced to Mauritius from shipwrecks before human settlement of the island, whereas macaques were probably introduced by early Portuguese explorers. Both species have been present in Mauritius for c. 400 years (Cheke, 1987).

Safford (1997c) found nesting success of Mauritius fodies to be higher in introduced, non-invasive Cryptomeria japonica trees (46\%) than in other tree species (6\%) and suggested that $C$. japonica provided some measure of protection from nest predators. This could either be nest concealment within dense foliage or the avoidance of C. japonica groves by mammalian predators because of low food availability and/or the sticky sap exuded by $C$. japonica (Safford \& Jones, 1998).

A programme to introduce Mauritius fodies to a predatorfree offshore island began in the 2002-2003 breeding season. This involved the harvesting of Mauritius fody nests and captive rearing of chicks for release onto the island. The study reported here resurveyed the entire population of Mauritius fody during the 2002-2003 breeding season and compared the nesting success of Mauritius fodies in pine Pinus spp. and C. japonica across four breeding seasons over 2002-2006. We also compare the nesting success of the mainland population to that of the released population on Ile aux Aigrettes during the breeding seasons of 2004-2005 and 2005-2006. 


\section{Study area}

The study was carried out in south-west Mauritius and on Ile aux Aigrettes, a 25 ha island $625 \mathrm{~m}$ off the south-east coast of Mauritius (Fig. 1). The mainland area is a heterogeneous mix of plantations of exotic, non-invasive species and degraded native forest. Both plantations and native forest are invaded by naturalized exotic plant species such as strawberry guava Psidium cattleianum, privet Ligustrum robustum and traveller's palm Ravenala madagascariensis. Pigeon Wood is a six hectare C. japonica grove surrounded by degraded native forest. Les Mares Chasse (a chasse is an area managed for hunting introduced game species), Alexandra Falls path, the Pines trail, Chasse Dayot and Bois Sec Chasse are pine plantations with some C. japonica and Eucalyptus robusta. Petrin and Gouly are native dwarf forests surrounded by pine plantations. Bassin Blanc, Combo and the land between Pigeon Wood and Bois Sec
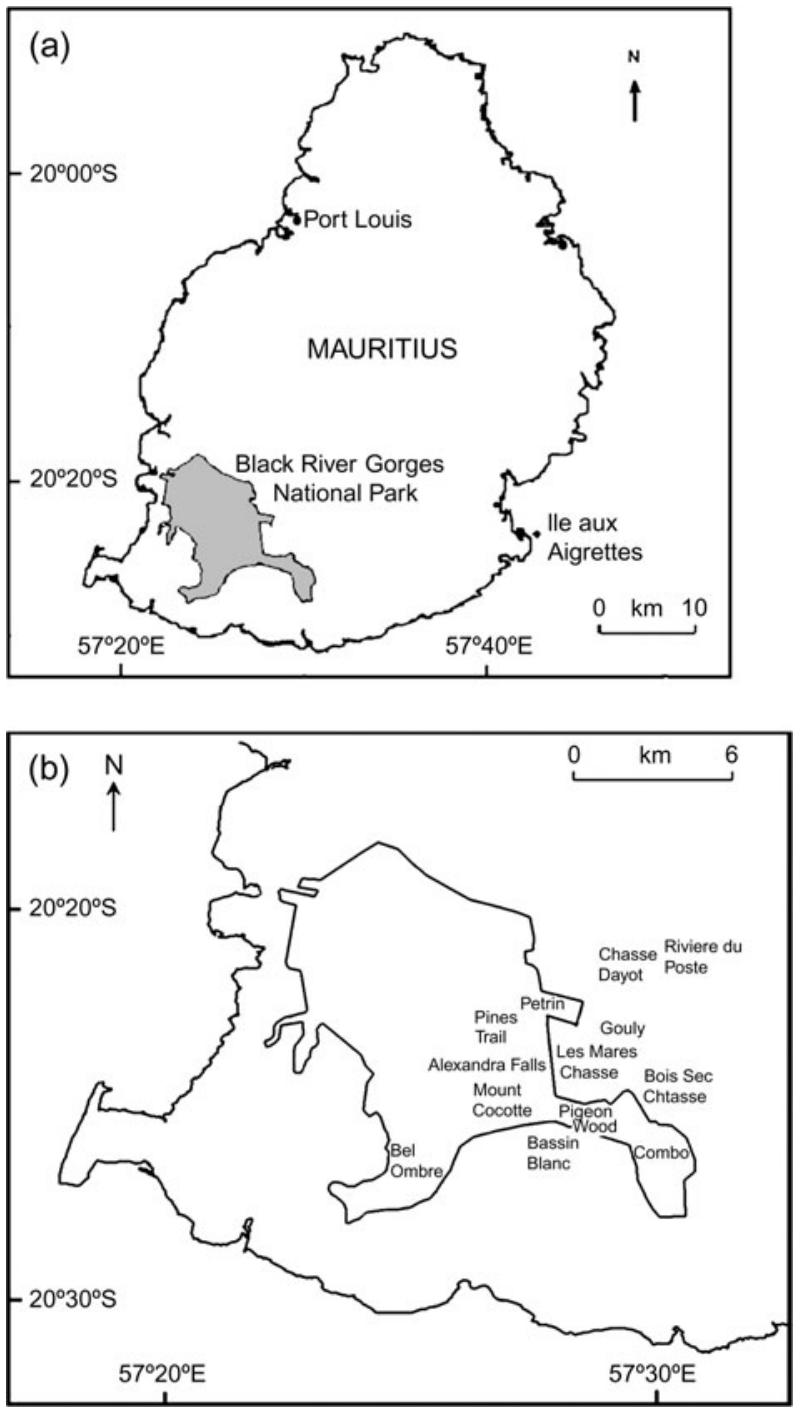

FIG. 1 (a) Mauritius, showing position of Black River Gorges National Park and Ile aux Aigrettes. (b) South-west Mauritius showing locations where the population census was carried out.
Chasse are areas of degraded native forest containing small plantations. Bel Ombre consists of degraded native forest with pine and tecoma Tabebuia pallida plantations. Mount Cocotte and Riviere du Poste are areas of good quality native forest, with understories invaded by exotics.

Ile aux Aigrettes contains the last remnant of native lowland ebony forest in Mauritius (Parnell et al., 1989). A continuous restoration programme involves the weeding of exotic species and planting of native species. Cats and rats have been eradicated from the island and crab-eating macaques were never introduced.

\section{Methods}

\section{Population census}

The population census used the same territory mapping techniques of previous surveys (Safford, 1997a). All areas where Mauritius fodies were likely to be found were given 'good' coverage, defined by Safford (1997a) as 'when no locality was more than $1 \mathrm{~km}$ from a route walked and total effort exceeded $8 \mathrm{~h} \mathrm{~km}^{-2}$ apart from Bel Ombre, Chasse Dayot and Gouly Pere, which received 'fair' coverage, defined by Safford (1997a) as 'when no locality was more than $3 \mathrm{~km}$ from a route walked and the total effort exceeded $2 \mathrm{~h} \mathrm{~km}^{-2}$. The small patch of native forest at Riviere du Poste and an area to the west of Piton Savanne that contained three fody territories in 1993 could not be accessed. The identity of the dominant canopy tree species in each mapped territory was recorded. It was assumed this would be the main nest tree species used by the pair within the territory. The population was divided into different subpopulations based on clusters of territories.

\section{Nesting success}

Nests were usually found by following adults carrying material. They were observed at least once every 2 days from at least $10 \mathrm{~m}$ away from the base of the nest tree. Nests were usually watched for 1 hour at each visit after incubation had started. If the parents were still building, the watch finished as soon as the stage of the nesting cycle could be confirmed to decrease the probability of a nest being abandoned because of the presence of an observer. If incubation had not been recorded, nest observations continued for at least 2 weeks after the last activity observed at the nest. If no activity was seen at a nest where the female was known to be incubating, brooding or feeding chicks and there was no obvious damage to the nest, the watch was extended until the failure of the nest could be confirmed. The contents of failed nests were checked, if this was possible, and any signs of predation were recorded.

The outcome of a nest was defined as: failed before incubation, if the nest was abandoned or attacked by predators 
before incubation was observed; failed after incubation started, if incubation had started but the nesting attempt was unsuccessful; harvested, if the nest contents were taken for hand rearing; successful, if fledglings were observed outside of the nest; unknown, if the nesting attempt could not be followed to its conclusion.

The daily probability of nest survival on the mainland and Ile aux Aigrettes was calculated using the Mayfield method (Mayfield, 1961) with confidence limits from Johnson (1979). This method is based on the number of days that nests are exposed to failure and allowed the inclusion of nests that were harvested before the outcome of the nest could be observed and nests that were found after incubation had begun. To calculate nesting success on the mainland the nesting period from the start of incubation to fledging was assumed to be 32 days (Safford, 1994). Only nests where incubation by the female or feeding of chicks by either parent was observed were included in Mayfield analyses.

\section{Results}

\section{Population census}

The territories of 93 pairs and two unpaired males were mapped in 2002-2003, providing an estimated total of 98-126 pairs (Table 1). In Fig. 2 the distribution of the Mauritius fody in 2002-2003 is compared to that of previous surveys. The total area of occupancy is $15.6 \mathrm{~km}^{2}$, assuming the native patch at Riviere du Poste is still occupied. Fody territories were unevenly distributed throughout their range. The area in and around the Pigeon Wood C. japonica grove holds the highest density of fodies (1.33 pairs ha $\left.{ }^{-1}\right)$. Twelve pairs had at least part of their territory in the 6 ha $C$. japonica grove at Pigeon Wood. Densities in other areas are difficult to define because of unoccupied gaps between territories.

A total of $84 \%$ (78/93) of mapped pairs held territories dominated by exotic trees compared to $16 \%(15 / 93)$ holding territories dominated by native trees (Table 1). Pine is the most frequent dominant tree species, with $48 \%$ of pairs having territories in which pine is dominant, and $26 \%$ where C. japonica is dominant. Nests were found in 43 of the $93(46 \%)$ mapped territories and the nesting tree species used by the pair was found to be the same as the dominant canopy tree species in 93\% (40/43) of these territories. Almost all nests were found within the Pigeon Wood C. japonica grove and Les Mares Chasse pine plantation so nesting tree species could be confirmed for most pairs in these areas (Table 1). The nesting tree species was not directly confirmed for most pairs thought to be nesting in native trees.

\section{Nesting success}

A total of 145 Mauritius fody nests were found on the mainland and 138 on Ile aux Aigrettes (Table 2). Fifty-eight percent (75/130) of the nests found on the mainland during building that could be followed to their conclusion did not proceed to incubation. Nineteen of these showed some damage caused by predators and five disappeared from the tree. The rest appeared undamaged $(51,39 \%$ of total nests found) and may have been abandoned. On Ile aux Aigrettes, $51.4 \%$ of nests were abandoned before incubation started. There was no significant difference in the probability of a nest found during building reaching incubation stage if it was in a C. japonica or pine tree (Log likelihood, $\chi_{1}^{2}=1.071$, $\mathrm{P}=0.301)$ or if it was on Ile aux Aigrettes or the mainland (Log likelihood, $\chi_{1}^{2}=0.05, \mathrm{P}=0.822$ ).

Nesting success in C. japonica was $35 \%$ (95\% confidence interval, CI, 22-58\%, 41 nests, 564 exposure days) and $34 \%$ in pine (95\% CI 16-75\%, 20 nests, 242 exposure days). Sample sizes were too small to give a meaningful estimate of success in other trees (three nests, 37 exposure days). Nesting success was similar between breeding seasons on the mainland except for the 2005-2006 season when it was much higher but the $95 \%$ confidence intervals overlap because of small sample sizes (Table 3). Eleven of the $27(40.7 \%)$ nests on the mainland that failed after incubation started were damaged by predators, and predation could be ruled out in $18.5 \%$ of cases (four infertile clutches, one brood died because of unknown causes). At the remaining failed nests it was unclear whether predation had occurred. Four had completely disappeared from the tree and the other seven had no visible damage but their contents had either disappeared or could not be checked. On Ile aux Aigrettes there was no clear evidence of predation at any nests that failed.

The daily probability of nest survival on the mainland was 0.968 (95\% CI 0.956-0.980, 64 nests, 842 exposure days) compared to 0.957 on Ile aux Aigrettes (95\% CI $0.945-$ $0.969,67$ nests, 1,086 exposure days). The mean time from the start of incubation to fledging on Ile aux Aigrettes was 29 days, giving a nesting success of $28 \%$ ( $95 \%$ CI $16-37 \%$ ) compared to $35 \%$ (95\% CI $24-54 \%$ ) on the mainland.

\section{Discussion}

The size of the mainland Mauritius fody population has remained stable over 10 years but there have been major changes in the distribution of the population, with exotic tree plantations playing an increasingly important role. Nesting success in pine trees was comparable to that in C. japonica and although nest predation was a common cause of failure, nesting success in plantations was similar to that in a released population on an offshore island where the mammalian predators of Mauritius fody nests are not present.

The number of Mauritius fodies has remained at c. 100-125 pairs over 1993-2003 and the area of occupancy has increased slightly from 14.7 to $15.6 \mathrm{~km}^{2}$. Although both these parameters have remained stable, the distribution of Mauritius fodies has shown a marked shift over the past 
TABLE 1 Mauritius fody territories mapped in surveys in 1992-1993, 1998-2001 and 2002-2003, with estimated nest tree species for pairs mapped in 2002-2003, and number of pairs for which nest species was confirmed. Numbers from 1992-1993 and 1998-2001 were taken from the territory maps of Safford (1994) and Nichols et al. (2002). For location of areas see Fig. $1 b$.

\begin{tabular}{|c|c|c|c|c|c|c|}
\hline Area & $\begin{array}{l}\text { No. of } \\
\text { territories } \\
\text { mapped } \\
1992-1993\end{array}$ & $\begin{array}{l}\text { No. of } \\
\text { territories } \\
\text { mapped } \\
1998-2001\end{array}$ & $\begin{array}{l}\text { No. of } \\
\text { territories } \\
\text { mapped } \\
\text { 2002-2003 }\end{array}$ & $\begin{array}{l}\text { No. of } \\
\text { territories } \\
\text { estimated } \\
2002-2003\end{array}$ & $\begin{array}{l}\text { Estimated nest tree } \\
\text { species of mapped } \\
\text { pairs in 2002-2003 } \\
\text { (n) }\end{array}$ & $\begin{array}{l}\text { No. of pairs for which } \\
\text { nest tree species was } \\
\text { confirmed }\end{array}$ \\
\hline Pigeon Wood $^{1}$ & 18 & 14 & 15 & 15 & $\begin{array}{l}\text { C. japonica (13) } \\
\text { Ravenala (1) } \\
\text { Native (1) }\end{array}$ & 15 \\
\hline Les Mares Chasse & 0 & 23 & 29 & $29-30$ & $\begin{array}{l}\text { Pine (27) } \\
\text { C. japonica (2) }\end{array}$ & 21 \\
\hline Alexandra Falls and Chamarel Road & 3 & 3 & 8 & $8-10$ & $\begin{array}{l}\text { Pine (5) } \\
\text { C. japonica (3) }\end{array}$ & 4 \\
\hline Mount Cocotte & 11 & 13 & 9 & $10-12$ & $\begin{array}{l}\text { Pine (1) } \\
\text { Native (8) }\end{array}$ & 0 \\
\hline Bassin Blanc & 11 & 8 & 7 & $7-8$ & $\begin{array}{l}\text { E. robusta (4) } \\
\text { Native }(3)\end{array}$ & 1 \\
\hline Pigeon Wood to Bois Sec Chasse & 16 & 10 & $7^{2}$ & $9-13$ & $\begin{array}{l}\text { C. japonica (1) } \\
\text { Native (2) } \\
\text { Ravenala (1) } \\
\text { E. robusta (3) }\end{array}$ & 0 \\
\hline Combo & 4 & 4 & $4^{3}$ & $4-6$ & C. japonica (2) & 0 \\
\hline Petrin to Grand Bassin & 5 & 5 & 6 & $6-8$ & $\begin{array}{l}\text { Pine (5) } \\
\text { C. japonica (1) }\end{array}$ & 1 \\
\hline Chasse Dayot & 0 & 0 & 5 & $5-8$ & $\begin{array}{l}\text { Pine (3) } \\
\text { C. japonica (2) }\end{array}$ & 0 \\
\hline Riviere du Poste & 4 & 4 & $0^{4}$ & $0-4$ & & \\
\hline Pines trail & 0 & 2 & 1 & $1-2$ & Pine (1) & 0 \\
\hline Bois Sec Chasse & 0 & 2 & 1 & $1-4$ & Pine (1) & 0 \\
\hline Gouly Pere & 2 & 2 & 0 & 0 & & \\
\hline Bel Ombre & 15 & 5 & 3 & $5-8$ & $\begin{array}{l}\text { Pine (2) } \\
\text { Native (1) }\end{array}$ & 1 \\
\hline Total & 86 & 95 & 95 & $100-128$ & $\begin{array}{l}\text { Pine (45) } \\
\text { C. japonica (26) } \\
\text { Native (15) } \\
\text { E. robusta }(7) \\
\text { Ravenala (2) }\end{array}$ & 43 \\
\hline
\end{tabular}

\footnotetext{
${ }^{1}$ Includes all territories south of the vehicle track between Pigeon Wood C. japonica grove and Les Mares Chasse

${ }^{2}$ Three territories mapped in this area in 1992-1993 could not be checked in 2002-2003

${ }^{3}$ Includes two single males

${ }^{4}$ This area was only visited on one occasion, for less than 1 hour, in 2002-2003
}

decade with birds starting to hold territories in habitats composed almost totally of exotic species, such as the pine plantation in Les Mares Chasse. This chasse now holds $23-31 \%$ of the population despite having been carefully searched and found to have no fodies in 1992-1993 (R. Safford, pers. comm.). Fodies also appear to have spread into Chasse Dayot, a similar area of pine plantation with the exotic Callistemon citrinus planted along paths. This area was visited, but not thoroughly checked for fodies, in 1993 (R. Safford, pers. comm.). C. citrinus appears to be an important source of nectar for Mauritius fodies in these chasses and pairs spent long periods feeding in these trees (A. Cristinacce, pers. obs.). It seems likely that fodies may begin to spread into areas of similar habitat in future years.
The largest decreases in the population have occurred at Bel Ombre, where numbers of pink pigeons Columba mayeri and Mauritius olive white-eyes Zosterops chloronthos have also declined in recent years (Nichols et al., 2004; Bunbury, 2006). The remaining Mauritius fody pairs at Bel Ombre are clustered around a small pine plantation and nest predation by introduced mammals in native trees may be causing these declines.

An estimated $63 \%$ of Mauritius fody pairs nested in exotic tree species in 1993 (Safford, 1994) but this has increased to $84 \%$ by 2003 . The only area where fodies are now estimated to nest in native trees in any number is on the southern slopes of Mount Cocotte where there are c. 10 pairs. Nesting in exotic trees seems to be common within the 

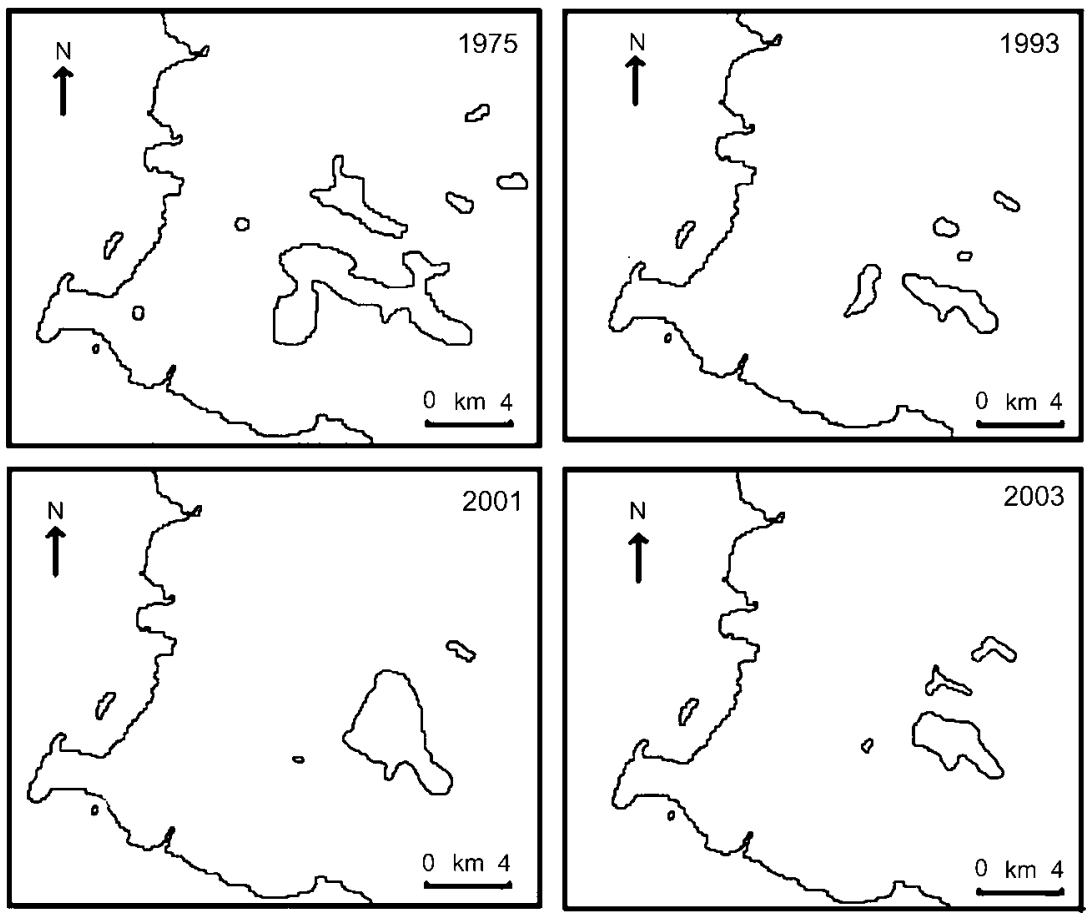

Fig. 2 Changes in distribution of Mauritius fodies in south-west Mauritius (Fig. 1b) over time. Maps from 1975, 1993 and 2001 are taken from Safford (1997b) and Nichols et al. (2002).
Foudia genus where introduced predators occur. Aldabran fodies Foudia eminentissima aldabrana nest in higher densities in introduced coconut Cocos nucifera (Frith, 1976) and the greatest densities of the Rodrigues fody Foudia flavicans were found in a plantation of Araucaria cunninghamii (Impey et al., 2002).

The highest densities of Mauritius fodies remain around Pigeon Wood, and the number of pairs including the

TABLE 2 Outcome of Mauritius fody nests found in different tree species on the mainland between the 2002-2003 and 2005-2006 seasons and on Ile aux Aigrettes in the 2004-2005 and 2005-2006 seasons.

\begin{tabular}{|c|c|c|c|c|}
\hline \multirow[b]{2}{*}{ Outcome } & \multicolumn{3}{|l|}{ Mainland } & \multirow{2}{*}{$\begin{array}{l}\text { Ile aux Aigrettes } \\
\text { All }\end{array}$} \\
\hline & C. japonica & Pine & Others $^{1}$ & \\
\hline $\begin{array}{l}\text { Failed before } \\
\text { incubation }^{2}\end{array}$ & 39 & 32 & 4 & 71 \\
\hline $\begin{array}{l}\text { Failed after } \\
\text { incubation started }\end{array}$ & 18 & 8 & 1 & 47 \\
\hline Harvested & 17 & 11 & 1 & 0 \\
\hline Successful & 5 & 1 & 1 & 20 \\
\hline Unknown $^{3}$ & 4 & 2 & 1 & 0 \\
\hline Total & 83 & 54 & 8 & 138 \\
\hline
\end{tabular}

${ }^{1}$ Other tree species used for nesting were Litsea spp., Ravenala madagascarensis, Tabernaemontana persicarifolia (native), Psidium cattleianum, Callistemon citrinus, Bertiera zaluznaia and a tangle of Rubus alceifolius, Psidium cattleianum and Isachne spp. (a native grass) ${ }^{2}$ Thirteen nests were found after incubation had started so could not be included in this category (six in C. japonica, one in pine, one in Others, and five on Ile aux Aigrettes)

${ }^{3}$ These nests were still active but could not be monitored further. One was incubating and six were at nest building stage.
C. japonica grove as part of their territory has increased from nine to 12. Safford (1994) attributed the high densities to the habitat structure available in the grove, with fodies able to include $C$. japonica trees for nesting and native vegetation for feeding within a small territory. It is now apparent that Mauritius fodies are able to survive in areas of almost entirely exotic vegetation, although at lower densities than in Pigeon Wood.

Safford (1997c) found that the nesting success of Mauritius fodies was mainly influenced by nest tree species, with nests in C. japonica showing a much higher probability of fledging chicks than nests in other tree species. He suggested that nests in pine and E. robusta may have a success rate intermediate between $C$. japonica and native trees but did not have sufficient sample sizes to test this. Our study found that nesting success in pine and C. japonica was similar. There were not enough samples to compare nesting success in other nest trees but the population census showed that few Mauritius fody pairs are now thought to nest in

Table 3 Nesting success (Mayfield Index; Mayfield, 1961) of Mauritius fodies on the mainland in different breeding seasons.

\begin{tabular}{|c|c|c|c|c|}
\hline Season & $\begin{array}{l}\text { Nesting } \\
\text { success } \\
(\%)\end{array}$ & $\begin{array}{l}95 \% \\
\text { confidence } \\
\text { limits }\end{array}$ & $\begin{array}{l}\text { No. of } \\
\text { exposure } \\
\text { days }\end{array}$ & $\begin{array}{l}\text { No. of } \\
\text { nests } \\
\text { followed }\end{array}$ \\
\hline $2002-2003$ & 30 & $14-63$ & 268 & 18 \\
\hline 2003-2004 & 35 & $19-66$ & 342 & 22 \\
\hline 2004-2005 & 26 & $8-85$ & 125 & 13 \\
\hline $2005-2006$ & 74 & $41-134$ & 108 & 11 \\
\hline
\end{tabular}


E. robusta or native trees so it is probable that nesting success is low in these species.

Many nests on the mainland failed because of predation but the nesting success in plantations was similar to that on a predator-free offshore island. Predation on the mainland could have masked other causes of failure. The fodies on Ile aux Aigrettes were mostly in their first breeding season and inexperience could have led to a lower nesting success. It may also explain the high percentage of nests that were abandoned there, although this could also be because of disturbance caused by observers or tourists on the island. Nests on Ile aux Aigrettes had a similar probability of reaching incubation to those on the mainland and damage to nests caused by predators prior to incubation may have disguised higher rates of abandonment on the mainland. Safford (1997c) found $30 \%$ of Mauritius fody nests were abandoned on the mainland, which is slightly lower than the $39 \%$ found in this study.

During the 2005-2006 season nesting success was higher on the mainland than in previous seasons although sample sizes were low. Crab-eating macaques were regularly removed from the study area during this season (R.E. Cole, pers. obs.), which may have reduced their overall density. There is a need for research into the effects of these introduced macaques on native birds in Mauritius. Carter \& Bright (2002) showed that macaques predate surrogate nests more often in native forest than in C. japonica plantations but pine plantations were not included in that study. Research on the densities of macaques in different forest types and any changes in nesting success following removal of macaques from an area would give a clearer picture of their impact on Mauritian avifauna.

The population size of Mauritius fodies in the uplands is stable, but numbers are still below those recorded in 19731975 (Cheke, 1983). Pine plantations used as hunting chasses, such as Les Mares, Dayot and Bois Sec, will become increasingly important to the population if current trends continue. Les Mares is also increasingly being used by pink pigeons (Bunbury, 2006). There do not appear to be any plans to fell pine plantations in the near future but there is no legal protection to prevent this. Mauritius fodies did not start to use the pine plantation at Les Mares until the late 1990s, c. 25 years after it was planted. This highlights Mauritius fodies' dependence on mature forest and the timescale required to replace any such habitat that is destroyed.

Safford \& Jones (1998) proposed the planting of new groves of non-invasive exotic trees to provide safe nesting sites for native birds in conjunction with native areas for feeding. A small C. japonica grove was planted around the field station at Pigeon Wood in 2003 but many of these young trees have since died (A. Cristinacce, pers. obs.). The plantations currently used by Mauritius fodies will not regenerate and more active planting of non-invasive exotic tree species as safe nesting sites for endemic birds may be required. Any plantations should try to mimic the structure and species composition of Pigeon Wood C. japonica grove where the highest densities of Mauritius fodies are found.

The destruction of the native Pandanus thickets at Les Mares in the 1970 s is believed to have taken away the last native habitat that provided a refuge for native birds from introduced mammalian predators (Safford, 1997b). The creation of similar habitats in Mauritius would provide a more satisfactory refuge for endemic birds than exotic plantations and would increase the diversity of other native taxa. It would currently be unacceptable to destroy the pine plantation at Les Mares to establish a native Pandanus thicket because of its importance to Mauritius fody and pink pigeon populations but research into restoring this type of habitat in other marshy areas of Mauritius should be conducted. This could be followed by reintroductions of native taxa if they are unlikely to spread into such restored habitats through natural dispersal.

Reducing predation by fencing has been used successfully to reintroduce North Island saddlebacks Philesturnus rufusater to mainland New Zealand, where they have also been recently reintroduced into unfenced areas with intensive predator control (Armstrong \& Davidson, 2006). However, there are no monkeys present on New Zealand and fences to exclude macaques from native Mauritian forest would require a break of at least $5 \mathrm{~m}$ either side of the fence (T. Day, Xcluder Fencing, pers. comm.). With the small area of native forest remaining in Mauritius (Safford, 1997d), removing this amount of native vegetation would be unacceptable. Predator control would require a continuous effort on mainland Mauritius as total eradication of introduced mammals is not currently feasible.

The Mauritius fody has been successfully released on to Ile aux Aigrettes, with the provision of supplementary food (Garrett et al., 2007), and the population had increased to over 50 pairs by the end of the 2007-2008 breeding season (L. Garrett, pers. comm.). Other islets around Mauritius have been cleared of exotic mammals (Bell, 2002) and may be suitable for Mauritius fodies. Gunners Quoin ( $76 \mathrm{ha}$ ), Flat Island (253 ha) and Round Island (169 ha) are all larger than Ile aux Aigrettes and may be able to support unmanaged populations of Mauritius fodies. Trial releases of Mauritius fodies on Round Island are planned for the 20082009 breeding season (L. Garrett, pers. comm.).

The upland Mauritius fody population is dependent upon plantations of non-invasive exotic tree species for its continued existence. Nesting success in these areas is similar to that on offshore islands where mammalian predators are absent, and the current trends showing a movement of the population into plantations are likely to continue. In areas where the eradication or control of predators is not feasible, management of non-invasive exotic plantations can be used to benefit endemic birds, although creation of native habitat refuges on the mainland and offshore islands should be explored. 


\section{Acknowledgements}

This work was funded by Chester Zoo, the Ruth Smart Foundation, Hong Kong Bank (Mauritius) and Thrigby Hall Wildlife Gardens. It was carried out with the support and collaboration of the Mauritius National Parks and Conservation Service. Special thanks to Andrew Bowkett, Amanda Ladkoo, Franzi Hillig, Jessica Steiner, Lucy Garrett and Sarah James for finding fody territories and nests and to Vikash Tatayah for providing maps of Mauritius. The manuscript was improved by comments from Malika Virah-Sawmy and an anonymous reviewer.

\section{References}

Armstrong, D.P. \& Davidson, R.S. (2006) Developing population models for guiding reintroductions of extirpated bird species back to the New Zealand mainland. New Zealand Journal of Ecology, $30,73-85$.

BELL, B.D. (2002) The eradication of alien mammals from five offshore islands, Mauritius, Indian Ocean. In Turning the Tide: The Eradication of Invasive Species (eds C.R. Veitch \& M.N. Clout), pp. 40-45. IUCN/SSC Invasive Species Specialist Group, IUCN, Gland, Switzerland and Cambridge, UK.

Bunbury, N.J. (2006) Parasitic disease in the endangered Mauritian pink pigeon Columba mayeri. $\mathrm{PhD}$ thesis, University of East Anglia, Norwich, UK.

Butchart, S.H.M., Stattersfield, A.J. \& Collar, N.J. (2006) How many bird extinctions have we prevented? Oryx, 40, 266-278.

CARter, S.P. \& BRight, P.W. (2002) Habitat refuges as alternatives to predator control for the conservation of endangered Mauritian birds. In Turning the Tide: The Eradication of Invasive Species (eds C.R. Veitch \& M.N. Clout), pp. 71-78. IUCN/SSC Invasive Species Specialist Group, IUCN, Gland, Switzerland and Cambridge, UK.

Chere, A.S. (1983) Status and ecology of the Mauritius fody Foudia rubra, an endangered species. National Geographic Society Research Reports, 15, 43-56.

Cheke, A.S. (1987) An ecological history of the Mascarene Islands with particular reference to extinctions and introductions of land vertebrates. In Studies of Mascarene Island Birds (ed. A.W. Diamond), pp. 5-89. Cambridge University Press, Cambridge, UK.

Duncan, R.P. \& Blackburn, T.M. (2007) Causes of extinction in island birds. Animal Conservation, 10, 149-150.

Frith, C.B. (1976) A twelve-month field study of the Aldabran fody Foudia eminentissima aldabrana. Ibis, 118, 155-178.

Garrett, L.J.H., Jones, C.G., Cristinacce, A. \& Bell, D.J. (2007) Competition or co-existence of reintroduced, critically endangered Mauritius fodies and invasive Madagascar fodies in lowland Mauritius? Biological Conservation, 140, $19-28$.

Impey, A.J., Côté, I.M. \& Jones, C.G. (2002) Population recovery of the threatened endemic Rodrigues fody (Foudia flavicans) (Aves, Ploceidae) following reforestation. Biological Conservation, 107, 299-305.
IUCN (2007) 2007 IUCN Red List of Threatened Species. IUCN, Gland, Switzerland. Http://www.iucnredlist.org [accessed 17 September 2008].

Johnson, D.H. (1979) Estimating nest success: the Mayfield method and an alternative. $A u k, 96,651-661$.

Johnson, T.H. \& Stattersfield, A.J. (1990) A global review of endemic birds. Ibis, 132, 167-180.

MAYfield, H.F. (1961) Nesting success calculated from exposure. Wilson Bulletin, 73, 255-261.

Nichols, R.K., Philips, P., Jones, C.G. \& Woolaver, L.G. (2002) Status of the Critically Endangered Mauritius fody Foudia rubra in 2001. Bulletin of the African Bird Club, 9, 95-100.

Nichols, R.K., Woolaver, L.G. \& Jones, C.G. (2004) Continued decline and conservation needs of the Endangered Mauritius olive white-eye Zosterops chloronthus. Oryx, 38, 291-296.

Parnell, J.A., Cronk, Q., Wyse Jackson, P. \& Strahm, W. (1989) A study of the ecological history, vegetation and conservation management of Ile aux Aigrettes, Mauritius. Journal of Tropical Ecology, 5, 355-374.

Penloup, A., Martin, J.-L., Gory, G., Brunstein, D. \& Bretagnolle, V. (1997) Distribution and breeding success of pallid swifts, Apus pallidus, on Mediterranean islands: nest predation by the roof rat, Rattus rattus, and nest site quality. Oikos, $80,78-88$.

S AFFORD, R.J. (1994) Conservation of the forest-living native birds of Mauritius. PhD thesis, University of Kent, Canterbury, UK.

SAFFORD, R.J. (1997a) Distribution studies on the forest-living native passerines of Mauritius. Biological Conservation, 80, 189-198.

SAFFORD, R.J. (1997b) The destruction of source and sink habitats in the decline of the Mauritius fody, Foudia rubra, an island-endemic bird. Biodiversity and Conservation, 6, 513-527.

SAFFORD, R.J. (1997c) Nesting success of the Mauritius fody Foudia rubra in relation to its use of exotic trees as nest sites. Ibis, 139, 555-559.

SAFFORD, R.J. (1997d) A survey of the occurrence of native vegetation remnants on Mauritius in 1993. Biological Conservation, 80, $181-188$.

SAFFord, R.J. \& Jones, C.G. (1998) Strategies for land-bird conservation on Mauritius. Conservation Biology, 12, 169-176.

Towns, D.R., Atrinson, I.A.E. \& Daugherty, S.H. (2006) Have the harmful effects of introduced rats on islands been exaggerated? Biological Invasions, 8, 863-891.

\section{Biographical sketches}

Andrew Cristinacce was co-ordinator of the Mauritian Wildlife Foundation Passerine Project between February 2004 and March 2006. Richard Switzer was Passerine Project Coordinator for the Mauritian Wildlife Foundation and Facility Manager of the Maui Bird Conservation Center for the Zoological Society of San Diego. $\mathrm{He}$ is currently Bird Curator at Al Wabra Wildlife Preservation. Ruth Cole was coordinator of the Mauritian Wildlife Foundation Passerine Project between March 2006 and 2008. CARL JONES is the Scientific Director of the Mauritian Wildlife Foundation and an International Research Fellow at the Durrell Wildlife Conservation Trust. He has managed conservation projects in Mauritius since 1979 including the restoration of the Mauritius kestrel, pink pigeon and echo parakeet. Diana BeLl has collaborated with the Mauritian Wildlife Foundation on research into threatened fauna and flora for the past 10 years. 